\title{
Kinetic model of development of acute viral infection in the human body. Critical conditions, control mechanisms, "thermoheliox"*
}

\author{
S. D. Varfolomeev, ${ }^{a, b}$ A. A. Panin, ${ }^{c}$ V. I. Bykov, ${ }^{b}$ S. B. Tsybenova, ${ }^{\star \star}$ L. V. Shogenova, ${ }^{d}$ and A. G. Chuchalin \\ ${ }^{a}$ Institute of Physicochemical Foundations of Functioning of Neural Network and Artificial Intelligence, \\ Lomonosov Moscow State University, \\ Build. 11B, 1 Leninskie Gory, 119991 Moscow, Russian Federation. \\ Fax: +7 (499) 9393589 \\ ${ }^{b}$ N. M. Emanuel Institute of Biochemical Physics, Russian Academy of Sciences, \\ 4 ul. Kosygina, 119334 Moscow, Russian Federation. \\ Fax: +7(499) 1374101 . E-mail: s.tsybenova@gmail.com \\ ${ }^{c}$ MedTechInnovations, \\ 3-1 Blagoveshchenskii per., 123001 Moscow, Russian Federation \\ ${ }^{d}$ N. I. Pirogov Russian State National Research Medical University, \\ 1 ul. Ostrovityanova, 117997 Moscow, Russian Federation
}

\begin{abstract}
A kinetic model of the development of acute viral infection is proposed and the dynamic behavior of key variables, including the concentrations of viral particles, infected cells, and pathogenic microorganisms, is described. The change in the hydrogen ion concentration in the lungs and $\mathrm{pH}$ dependence of the activity of carbonic anhydrase, a key respiration enzyme, are critical factors. An acute bifurcation transition determining either the life or collapse of the system is demonstrated. The transition is associated with exponential increase in the concentrations of participants in the process and with functioning of the key enzyme, carbonic anhydrase. A physicochemical interpretation is given for the therapeutic effect of temperature rise and potential therapeutic effect of "thermoheliox", that is, breathing by heated helium-oxygen mixture.
\end{abstract}

Key words: acute viral infection, kinetic model, carbonic anhydrase, parametric analysis, therapy, thermoheliox, coronavirus.

The infection of a living organism with viral particles, resulting in development of a clinical presentation potentially culminating in a collapse (death) of the organism, is a complex dynamic process. The most important parameters determining the process dynamics are the concentration of the infecting viral agent, the concentration of pathogenic microflora, which develops symbiotrophically on the affected cells, and physical conditions of the process such as temperature and $\mathrm{pH}$ of the medium. With the goal to create conditions for suppression of the viral infection and for controlling the treatment process, it appears highly expedient to construct and analyze kinetic models describing the development of the pathological process.

Quite a few publications of the last decade describe modeling of the dynamics of viral growth in the body, taking account of the production of pathogenic microflora and human immune system response. A review ${ }^{\mathbf{1}}$ surveys the mathematical models of the dynamics of influenza within an organism, including and not including the immune

* Dedicated to Academician of the Russian Academy of Sciences I. L. Eremenko on the occasion of his 70th birthday. response. ${ }^{1}$ Baccam et al. ${ }^{2}$ modified the simplest model of infection with the influenza virus by adding equations that take account of the delay of viral production (which is 6-8 h), interferon induction to inhibit the viral replication in an infected cell, and the process of treatment. Most of mathematical models describe the incubation, the viral growth, activation of the immune system, and treatment of infection, but they do not consider the causes for collapse of the system, that is, molecular causes for the death of an organism related to the disease. The mathematical models neglect the disturbance of the acid-alkaline balance $(\mathrm{pH}),{ }^{3}$ which plays an important role in the functioning of respiratory tract and metabolism. Increasing amount of carbon dioxide and accumulation of acid metabolites decreases $\mathrm{pH}$ of the blood and reduces the catalytic activity of carbonic anhydrase, which corresponds to respiratory acidosis.

\section{Results and Discussion}

Kinetic model. Here we present the mathematical model describing the growth dynamics of the viral infection,

Published in Russian in Izvestiya Akademii Nauk. Seriya Khimicheskaya, No. 6, pp. 1179-1184, June, 2020. 
formation of the pathogenic microflora, and change in the $\mathrm{pH}$ in the lesion. The kinetic model and its parametric analysis are presented below. The model is based on the kinetic equations reported in our previous studies $\mathrm{s}^{\mathbf{4}, 5}$ on the growth and evolution of microbial and viral populations.

The basic set of equations can be represented in the form

$$
\mathrm{d}[\mathrm{N}] / \mathrm{d} t=k_{1}[\mathrm{~N}]-\alpha(T)[\mathrm{N}], t=0,[\mathrm{~N}]=[\mathrm{N}]_{0},
$$

where $[\mathrm{N}]$ is the concentration of the infecting virus; $k_{1}$ is the specific viral replication rate in the body; $\alpha(T)$ is the parameter characterizing the rate of virus eradication by thermal inactivation, immune response, etc., $[\mathrm{N}]_{0}$ is the initial infecting concentration of the virus.

The virus penetrating into the host cells, first of all, into lung cells, replicates and destroys the infected cells. The metabolically destroyed cells represent a favorable medium for the growth of pathogenic microorganisms. The products are actually dead cells, they acts as a substrate for the growth of pathogenic microflora:

$$
\begin{aligned}
& \mathrm{d}[\mathrm{P}] / \mathrm{d} t=k_{2}[\mathrm{~N}], t=0,[\mathrm{P}]_{0}=0, \\
& \mathrm{~d}[\mathrm{M}] / \mathrm{d} t=\mu([\mathrm{P}])[\mathrm{M}]-\beta(T)[\mathrm{M}], t=0,[\mathrm{M}]=[\mathrm{M}]_{0},
\end{aligned}
$$

where $[\mathrm{P}]$ and $[\mathrm{M}]$ are the contents of products and microorganisms, respectively.

The specific growth rate of microorganisms $\mu([\mathrm{P}])$ depends on the concentration of dead cells $[\mathrm{P}]$ and can be expressed by the Monod equation:

$$
\mu([\mathrm{P}])=\mu_{\mathrm{m}}[\mathrm{P}](t) /\left\{K_{\mathrm{P}}+[\mathrm{P}](t)\right\},
$$

where $\mu_{\mathrm{m}}$ is the maximum specific growth rate; $K_{\mathrm{P}}$ is the pathogen affinity to the substrate (product), $\beta(T)$ is the parameter characterizing the thermal death of microorganisms.

The pathogenic mcroflora, e.g., pneumococci, are facultative anaerobes and, under limited aeration conditions, in poor air exchange areas, they utilize the anaerobic mechanism for ATP synthesis and thus produce organic acids. This is a way to local respiratory acidosis and collapse (death) of the organism.

It is known that $\mathrm{pH} \sim 7.15$ is the critical value in the blood circulation system. At lower $\mathrm{pH}$ in the blood, metabolism of the organism is disturbed. This is due to the fact that the active sites of many enzymes contain the imidazole group of histidine, the $\mathrm{p} K_{\mathrm{a}}$ of which is $7.0-7.2,{ }^{6}$ depending on the protein structure. Protonation of the imidazole group leads to complete loss of enzyme activity.

The key enzyme of functioning of the respiration system is carbonic anhydrase, which catalyzes carbonic acid transfer from the liquid to the gas phase as gaseous carbon dioxide:

$$
\mathrm{HCO}_{3}^{-} \longrightarrow \mathrm{CO}_{2}+\mathrm{OH}^{-} .
$$

The catalytic activity of this enzyme is determined by the imidazole group of histidine with $\mathrm{p} K_{\mathrm{a}} \sim 7.0$. Blocking the activity of this enzyme means complete termination of respiration.

Presumably, under conditions of considerable lung damage by pathogenic microflora, $\mathrm{pH}$ change in lungs by $0.2-0.3$ units is the major factor of collapse of the respiratory system.

In terms of the considered model, the dynamics of $\mathrm{pH}$ variation in the affected area can be described by Eq. (5) with the assumption that the proton production rate is proportional to the concentration of pathogenic microflora:

$$
\begin{aligned}
& \mathrm{d}\left[\mathrm{H}^{+}\right] / \mathrm{d} t=\gamma\left(\left[\mathrm{H}^{+}\right]_{0}-\left[\mathrm{H}^{+}\right]\right)+\delta[\mathrm{M}]-v_{\mathrm{c}}, \\
& t=0,\left[\mathrm{H}^{+}\right]=\left[\mathrm{H}^{+}\right]_{0} .
\end{aligned}
$$

The coefficient $\delta$ characterizes the productivity of microorganisms for proton generation and the buffer properties of the blood system. The term $\gamma\left(\left[\mathrm{H}^{+}\right]_{0}-\left[\mathrm{H}^{+}\right]\right)$ describes the "openness" of the system for protons, where $\left[\mathrm{H}^{+}\right]_{0}$ corresponds to the concentration of protons entering the damaged area, $\left[\mathrm{H}^{+}\right]$is the averaged proton concentration in the lesion, $\gamma$ is the mass transfer coefficient. The parameter $v_{\mathrm{c}}$ is the rate of the carbonic anhydrase enzymatic reaction, i.e., the rate of production of hydroxyl ions by the carbonic anhydrase-catalyzed reaction. Considering the $\mathrm{pH}$ dependence of the rate of enzymatic reaction, the rate equation can be presented in the form

$$
v_{\mathrm{c}}=\frac{V_{\mathrm{m}}\left[\mathrm{HCO}_{3}^{-}\right]}{\left(1+\left[\mathrm{H}^{+}\right] / K_{\mathrm{a}}\right)\left(K_{\mathrm{M}}+\left[\mathrm{HCO}_{3}^{-}\right]\right)}=\frac{A}{1+\left[\mathrm{H}^{+}\right] / K_{\mathrm{a}}},
$$

where $V_{\mathrm{m}}$ is the maximum rate of the catalytic reaction, $K_{\mathrm{M}}$ is the Michaelis constant.

Provided that the bicarbonate concentration is constant (relatively small portion of process development), the constant factor in Eq. (6) will be denoted by $A$.

Solution of the system of Eqs (1)-(6) gives a kinetic description for the observed development of the pathology upon infection with a coronavirus.

One of the scenarios of process development is shown in Fig. 1. Equations (1)-(6) were integrated using the following parameters: $k_{1}=2 \cdot 10^{-2} \mathrm{~h}^{-1}, k_{2}=10^{-2} \mathrm{~h}^{-1}$, $\alpha=5 \cdot 10^{-3} \mathrm{~h}^{-1}, \beta=10^{-3} \mathrm{~h}^{-1}, \gamma=0.1 \mathrm{~h}^{-1}, \delta=10^{-2} \mathrm{~h}^{-1}$, $\mathrm{m}_{\mathrm{m}}=2.5 \cdot 10^{-2} \mathrm{~mol} \mathrm{~L}^{-1} \mathrm{~h}^{-1}, K_{\mathrm{a}}=10^{-7.2} \mathrm{~mol} \mathrm{~L}^{-1}$, $K_{\mathrm{P}}=10^{-3} \mathrm{~mol} \mathrm{~L}^{-1}, A=5 \mathrm{~mol} \mathrm{~L}^{-1} \mathrm{~h}^{-1},[\mathrm{~N}](0)=10^{-3} \mathrm{~mol} \mathrm{~L}^{-1}$, $[\mathrm{P}](0)=0 \mathrm{~mol} \mathrm{~L}^{-1},[\mathrm{M}](0)=10^{-3} \mathrm{~mol} \mathrm{~L}^{-1},\left[\mathrm{H}^{+}\right](0)=$ $=\left[\mathrm{H}^{+}\right]_{0}=10^{-7.4} \mathrm{~mol} \mathrm{~L}^{-1}$.

The obtained solution qualitatively describes the infection phenomenon and development of the disease.

1. The incubation period, in which there are practically no signs of the disease. From Fig. 1 (dashed line), it is observed that with the parameters given above, this period is $\sim 150 \mathrm{~h}$ (approximately 6.5 days). 


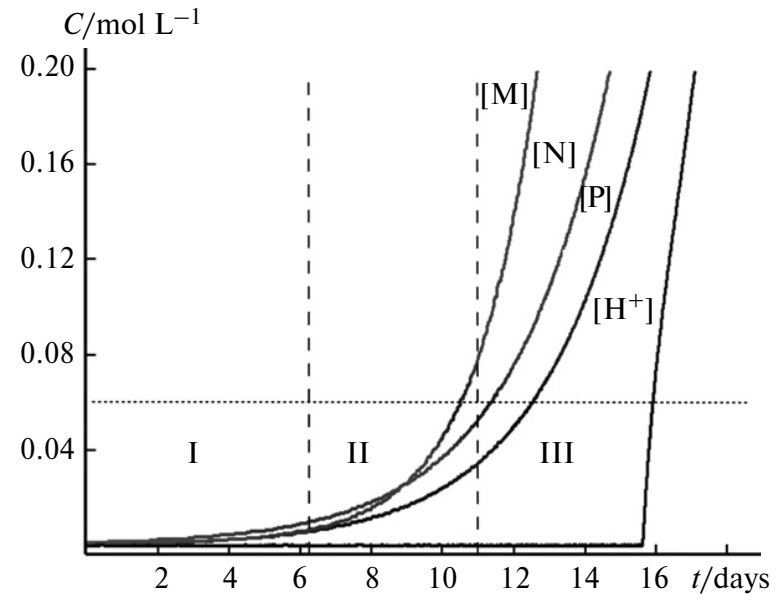

Fig. 1. Variation dynamics of concentrations of the virus $[\mathrm{N}]$, destroyed cells $[\mathrm{P}]$, pathogenic microflora $[\mathrm{M}]$, and hydrogen ions $\left[\mathrm{H}^{+}\right]$upon viral infection; (I) incubation period of the virus, (II) mild form of the disease, (III) severe form and collapse.

2. At the end of the incubation period (induction period), fast symbiotrophic increase in the virus concentration and pathogenic microflora concentration with significant accumulation of the virus and microorganisms is observed.

3. In the primary periods of pathology development (incubation period and initial period of active increase in the virus and pathogenic microflora concentrations), $\mathrm{pH}$ value in the damaged area is in the range of 7.2-7.4. In the absence of therapy or deliberate influence on the system behavior, bifurcation growth and $\mathrm{pH}$-based suppression of carbonic anhydrase activity take place. This should result in complete respiratory arrest. Using the above-indicated parameters, the model predicts that respiratory arrest will occur on the 15th or 16th day after infection. The collapse is of the bifurcation nature, and the transition point is easily identified in the plot (see Fig. 1). The bifurcation point is a crucially important characteristic of the process. This is the point of no return, actually, the time of death of the organism. When this point has been passed, the release of $\mathrm{CO}_{2}$ from the liquid phase to the gas phase is stopped. The uncontrolled increase in the bicarbonate concentration in blood takes place, i.e., breathing is blocked.

It is of interest to study the effect of variation of the parameters on the system behavior in order to identify the most sensitive elements and process control methods. Below we consider several important cases.

Control mechanisms. Virus destruction (immune response). The most sensitive parameter determining the system behavior is characteristics of the viral destruction rate (parameter $\alpha$ ). Under natural conditions, the destruction is based on activation of the immune system, which produces antibodies against viral proteins. In terms of our model, $\tau_{c}$, that is, the time of system existence before the collapse (life span after infection) is a highly convenient parameter describing the main process characteristics. This time can be visualized by integrating the set of equations and computations. The life span is the period before the bifurcation transition of the hydrogen ion concentration, the break point, and experimentally observed fast increase in $\left[\mathrm{H}^{+}\right]$(see Fig. 1). The dependence of $\tau_{\mathrm{c}}$ on the parameter $\alpha$ was studied by mathematical modeling methods. Figure 2 shows the time dependence of $\left[\mathrm{H}^{+}\right]$at various $\alpha$ and the derived dependence of $\tau_{\mathrm{c}}$ on $\alpha$.

The point $\alpha=k_{1}$ is the critical point in which the rate of growth of the virus concentration in the organism turns into zero. This is the condition of full recovery.

Antibiotics (suppression of the growth of the pathogenic microflora). The development of the infectious process is markedly affected by the growth rate of the pathogenic flora (see Eq. (4)). In the therapy, this process is controlled by administration of antibiotics, which inhibit the growth of microorganisms to one or another extent.

The results of a mathematical experiment studying the effect of the parameters $\mu_{\mathrm{m}}$ and $K_{\mathrm{P}}$ on the system life span are presented in Fig. 3. It can be seen that a decrease in the growth rate of microorganisms (decrease in $\mu_{\mathrm{m}}$ and increase in $K_{\mathrm{P}}$ ) has a beneficial effect on the life span, that is, the time before the bifurcation transition ( $\mathrm{pH}$ jump).

Key role of carbonic anhydrase. The carbonic anhydrase enzyme plays a fundamentally important role in the respiration mechanism, as it "discharges" the biochemically formed bicarbonate ion to gaseous $\mathrm{CO}_{2}$ and hydroxyl ion. Under normal physiological conditions ( $\mathrm{pH} \sim 7.4)$, this reaction is virtually irreversible (exhalation; the system is open for $\mathrm{CO}_{2}$ ). The catalytic activity of carbonic anhydrase is controlled by the ionogenic group with $\mathrm{p} K_{\mathrm{a}} \sim 7$ (see Eq. (6)). The $\mathrm{pH}$ shift (even a minor one) towards the acid region (decrease in the $\mathrm{pH}$ ) decreases the catalytic activity of the enzyme; the rate of production of $\mathrm{OH}^{-}$ions

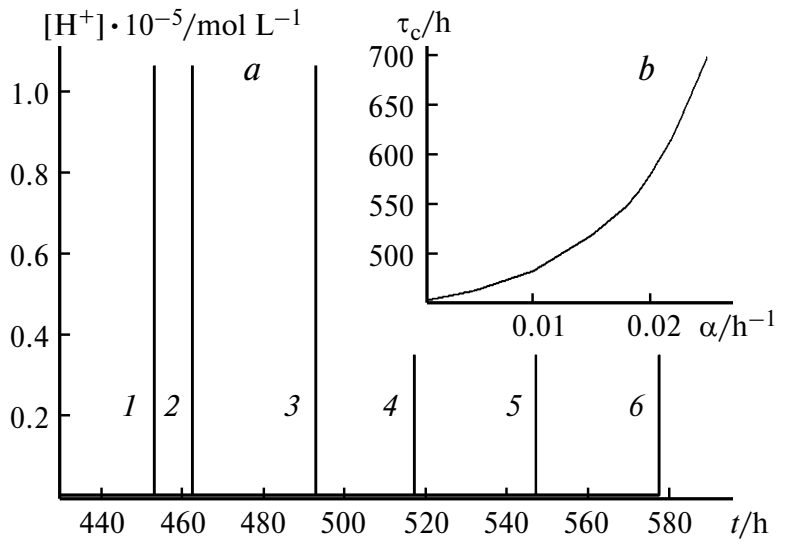

Fig. 2. Dynamics of the shift of bifurcation transition point of the hydrogen ion concentration $\left[\mathrm{H}^{+}\right](a)$ at $\alpha=10^{-3}$ (1), $5 \cdot 10^{-3}(2), 1.2 \cdot 10^{-2}(3), 1.5 \cdot 10^{-2}(4), 1.8 \cdot 10^{-2}(5)$, and $2 \cdot 10^{-2}(6)$ and dependence of $\tau_{\mathrm{c}} v s . \alpha(b)$. 


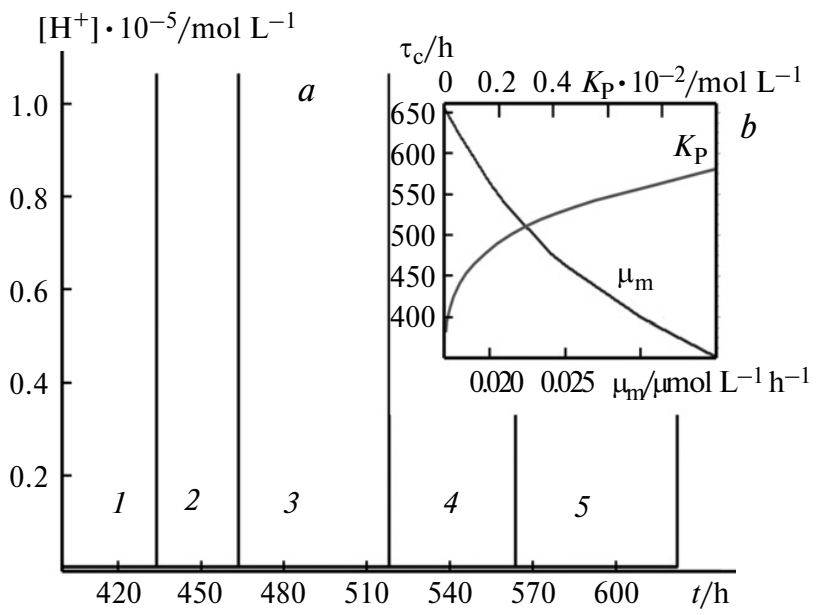

Fig. 3. Dynamics of the shift of bifurcation transition of hydrogen ion concentration $\left[\mathrm{H}^{+}\right](a)$ at $\mu_{\mathrm{m}}=0.027$ (1), 0.025 (2), $0.022(3), 0.020(4)$, and $0.018 \mathrm{~mol} \mathrm{~L}^{-1} \mathrm{~h}^{-1}(5)$ and dependence of $\tau_{\mathrm{c}}$ on the parameters $\mu_{\mathrm{m}}$ and $K_{\mathrm{P}}(b)$.

decreases in parallel. The process is self-accelerating and leads to the bifurcation $\mathrm{pH}$ jump.

The dependence of $\tau_{\mathrm{c}}$ on the catalytic activity of carbonic anhydrase $(A)$ is depicted in Fig. 4. It can be seen that the life span $\tau_{\mathrm{c}}$ can be considerably increased by increasing the enzyme activity. Carbonic anhydrase has a $\mathrm{Zn}^{2+}$ ion in the active site. This means that efficient therapy of a viral infection requires saturation of patient's metabolism with $\mathrm{Zn}^{2+}$ ions.

Therapeutic effect of high temperature. The natural development of the disease is associated with the rise of body temperature. The inflammatory response is initiated by a large set of biochemical reactions, including the synthesis of prostaglandin type inflammatory media-

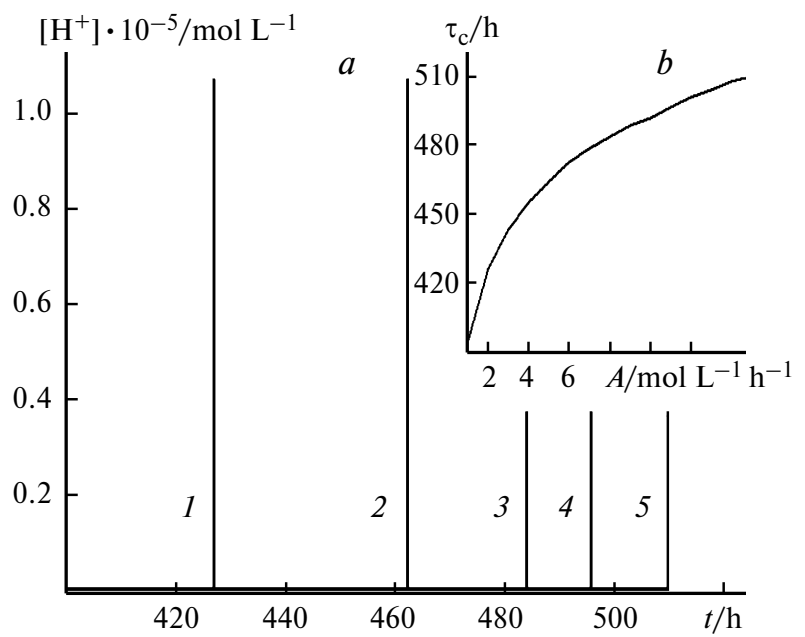

Fig. 4. Dynamics of the shift of bifurcation transition point of the hydrogen ion concentration $\left[\mathrm{H}^{+}\right](a)$ for $A=2(1), 5$ (2), $8(3), 11(4)$, and $15 \mathrm{~mol} \mathrm{~L}^{-1} \mathrm{~h}^{-1}(5)$ and dependence of $\tau_{\mathrm{c}}$ on the catalytic activity of carbonic anhydrase $A(b)$. tors ${ }^{7,8}$ and thermal shock proteins and activation of the immune system.

Temperature rise affects most appreciably the rate of thermal death of microorganisms and viruses. It is known that with increasing temperature, the concentration of viruses $([\mathrm{N}])$ and microorganisms decreases exponentially due to thermal death

$$
\begin{aligned}
& {[\mathrm{N}](t)=[\mathrm{N}]_{t} \exp \left(-k_{\mathrm{N}} \Delta t\right),} \\
& {[\mathrm{M}](t)=[\mathrm{M}]_{t} \exp \left(-k_{\mathrm{M}} \Delta t\right),}
\end{aligned}
$$

where $[\mathrm{N}]_{t}$ and $[\mathrm{M}]_{t}$ are the concentrations of pathogens at time point $t, \Delta t$ is the exposure time at elevated temperature, $k_{\mathrm{N}}$ and $k_{\mathrm{M}}$ are the kinetic characteristics of the thermal death of viruses and microorganisms, respectively (see, for example, Ref. 9; Figs 7.33 and 7.34).

A more detailed analysis of the data presented in the Figures cited in the book ${ }^{9}$ shows that the kinetic parameters of the thermal death $k_{\mathrm{N}}(t)$ and $k_{\mathrm{M}}(t)$ obey the classical Arrhenius equation:

$$
\begin{aligned}
& k_{\mathrm{N}}(t)=k_{\mathrm{N}}^{0} \exp \left[-\Delta H_{\mathrm{N}} * /(R T)\right], \\
& k_{\mathrm{M}}(t)=k_{\mathrm{M}}{ }^{0} \exp \left[-\Delta H_{\mathrm{M}}{ }^{*} /(R T)\right],
\end{aligned}
$$

where $\Delta H_{\mathrm{N}}{ }^{*}$ and $\Delta H_{\mathrm{M}} *$ are the activation energies of the thermal death of viruses and microorganisms, respectively.

Microorganisms, including pathogens, are very sensitive to temperature rise. Indeed, the rate of death of Escherichia coli increases 14.3-fold as the temperature increases from 54 to $60{ }^{\circ} \mathrm{C}$, and the rate of death of Staphylococcus aureus grows almost 5-fold as the temperature increases from 53 to $57^{\circ} \mathrm{C}$. In view of the published data, ${ }^{9}$ one can estimate $\Delta H_{\mathrm{M}}{ }^{*}=100 \mathrm{kcal} \mathrm{mol}^{-1}$ (thermal death of $S$. aureus) and $\Delta H_{\mathrm{M}}{ }^{*}=118 \mathrm{kcal} \mathrm{mol}^{-1}$ (thermal death of $E$. coli). If we assume that the thermal death of the viruses is determined by the thermal destruction of capsule proteins, then for rough calculations it can be taken that $\Delta H_{\mathrm{N}}{ }^{*}=40-50 \mathrm{kcal} \mathrm{mol}^{-1}$.

Within the framework of the model, it appears possible to consider direct inactivation of viruses and pathogenic microorganisms on going from the normal body temperature of $36{ }^{\circ} \mathrm{C}$ to the fever temperature of $41{ }^{\circ} \mathrm{C}$. If the activation energy of the thermal destruction of viruses is conventionally taken to be $40 \mathrm{kcal} \mathrm{mol}^{-1}$, transition from the normal temperature to the fever temperature causes the parameter $\alpha$ to increase 2.8-fold. According to calculations, the bifurcation collapse point shifts in this case from 360 to $420 \mathrm{~h}$. For the activation energy of $50 \mathrm{kcal} \mathrm{mol}^{-1}$, the $\alpha$ value increases 3.5 -fold, and the collapse shifts to $440 \mathrm{~h}$. Thus, the patient gets an additional portion of time to fight the disease.

A fundamentally important issue is the structure of Eq. (1). The exponential growth of the virus concentration is possible only for $k_{1}>\alpha$. In terms of the basic parameters 


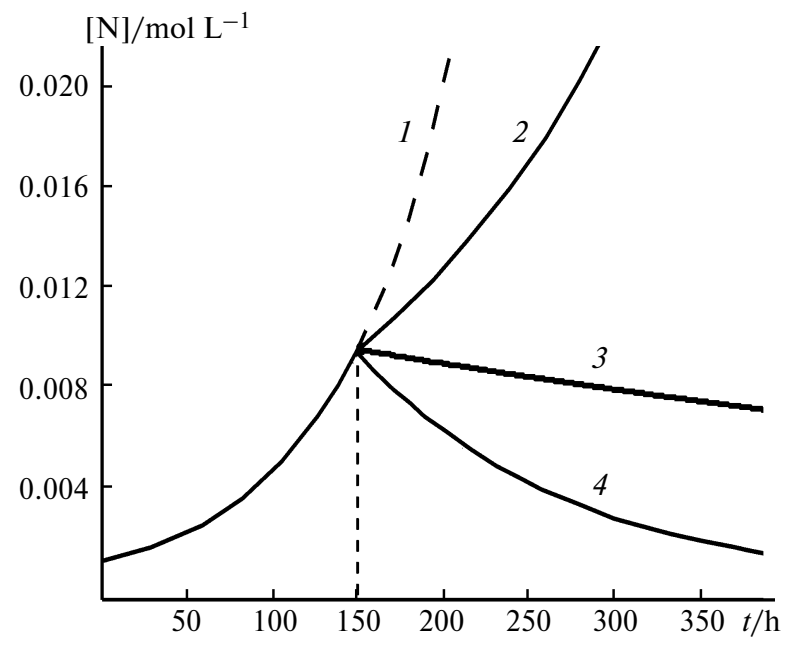

Fig. 5. Dynamic of the growth of virus concentration $(1, \alpha=0)$ and variation of the dynamics upon thermal inactivation processes: $\alpha=5 \cdot 10^{-3}(2), 7.5 \cdot 10^{-3}(3)$, and $10^{-2} \mathrm{~h}^{-1}(4)$.

of the model $\left(k_{1}=2 \cdot 10^{-2} \mathrm{~h}^{-1}, \alpha=5 \cdot 10^{-3} \mathrm{~h}^{-1}\right)$, a more than 4-fold increase in $\alpha\left(\alpha=2 \cdot 10^{-2} \mathrm{~h}^{-1}\right)$ leads to complete termination of the development of viral infection (complete therapeutic effect). The calculations illustrate and explain the therapeutic effect of increasing temperature (Fig. 5).

Using the kinetic model, it is possible to estimate the period of increased temperature that is needed for the therapeutic effect $\left(\Delta t_{\text {ther }}\right)$ :

$$
\Delta t_{\text {ther }}=\frac{\ln \left([\mathrm{M}]_{0} /[\mathrm{M}]\right)}{\gamma_{36}} \exp \left[\frac{\Delta H_{\mathrm{M}}^{*}}{R}\left(\frac{1}{T_{36}}-\frac{1}{T_{41}}\right)\right],
$$

where $[\mathrm{M}]_{0} /[\mathrm{M}]$ is the degree of cleaning of lungs from the microbiological pathogen, $\gamma_{36}$ is the kinetic parameter of the thermal death at $36^{\circ} \mathrm{C}\left(5 \cdot 10^{-3} \mathrm{~h}^{-1}\right), \Delta H_{\mathrm{M}}{ }^{*}$ is the activation energy of the thermal death of the microorganism, $T_{36}$ and $T_{41}$ are patient's normal and fever temperatures. The estimates show that a 10 -fold degree of microorganism inactivation $\left([\mathrm{M}]_{0} /[\mathrm{M}]=10\right)$ will be attained in $34 \mathrm{~h}$, while a 100-fold inactivation will take place in $65 \mathrm{~h}$.

Therapeutic effect of the thermoheliox. The use of thermoheliox, that is, a thermolyzed mixture of helium and oxygen appears to be the most promising therapeutic means to suppress the viral growth. The essence of this approach is the action on the patient's respiratory system with a thermolyzed mixture of oxygen and helium at a relatively high temperature. The therapeutic procedure is to make the patient breathe with a mixture of helium and oxygen ( $80-60 \%$ helium, $20-40 \%$ oxygen) with a temperature of $50-90^{\circ} \mathrm{C}$. The strategy of using a thermolyzed helium and oxygen mixture was scientifically substantiated in detail; it proved to be efficient in the treatment of respiratory pathologies, ischemic stroke, and pathologies of pregnancy. This method was successfully used for the treatment of more than 2500 patients of the pulmonary and neurology departments of the D. D. Pletnev State Clinical Hospital. ${ }^{10-12}$ A. A. Panin developed a unique medical device for controlling the composition and temperature of the helium-oxygen mixture and administration of medical drugs into lungs. ${ }^{\mathbf{1 3}}$ The available experimental and practical experience (the use in sauna baths for inhaling air at temperatures up to $100^{\circ} \mathrm{C}$ ) demonstrates that the thermolyzed oxygen and nitrogen mixture is virtually harmless to the human body within 20-30 minutes of exposure. The thermolyzed helium-oxygen mixture behaves in a similar way. Helium, which has a high diffusion ability, efficiently drains and shunts all tissues of the body and markedly increases the microcirculation in all organs and tissues. Thermoheliox substantially increases the oxygen delivery, decreases the resistance of respiratory tract, improves the ventilation/perfusion ratio via the alveolar capillary membrane in lungs, and maintains the acid-alkaline balance. The effect is thermoheliox is much more efficient than the effect of a room-temperature mixture of oxygen and helium. Mammalian and human cells use specialized protection mechanisms from temporary overheating (heat-shock proteins). Meanwhile, the virus is subjected to efficient destruction via protein and nucleic acid denaturation. Indeed, the influenza virus remains intact for only several minutes at $50-60{ }^{\circ} \mathrm{C}$, the $\mathrm{HIV}$ is inactivated 100 -fold within $30 \mathrm{~min}$ at $56^{\circ} \mathrm{C}$, the hepatitis virus loses activity within $2 \mathrm{~min}$ at $100{ }^{\circ} \mathrm{C}$, and the foot-and-mouth disease virus is destroyed within $5-10 \mathrm{~min}$ at $50-60^{\circ} \mathrm{C}$.

The essential instability of the viruses against elevated temperature accounts for the seasonal nature of airborne transmitted viral infections. A. A. Panin (January 2020) proposed using thermoheliox as a potential agent fir killing coronaviruses.

It is of interest to analyze the influence of thermoheliox in terms of the model of development of viral and bacterial damage discussed here. If the activation energy of the thermal destruction of the virus is taken to be $50 \mathrm{kcal} \mathrm{mol}^{-1}$, the exposure of the damaged area for $30 \mathrm{~min}$ at $60^{\circ} \mathrm{C}$ may decrease the concentration of the virus several-fold (Fig. 6). The subsequent exposures lead to a dramatic decrease in the concentrations of the pathogenic virus and microorganisms in the body.

It is possible to estimate the temperature dependence of the degree of destruction of the pathogenic virus $\left([\mathrm{N}] /[\mathrm{N}]_{0}\right)$ on a $30-\mathrm{min}$ respiratory exposure:

$$
\frac{[\mathrm{N}]}{[\mathrm{N}]_{0}}=\exp \left\{-\alpha\left(T_{36}\right) \Delta t_{\exp } \cdot \exp \left[-\frac{\Delta H_{\mathrm{M}}^{*}}{R}\left(\frac{1}{T_{\mathrm{w}}}-\frac{1}{T_{36}}\right)\right]\right\},
$$

where $\alpha\left(T_{36}\right)$ is the kinetic parameter at a normal body temperature (in this case, $5 \cdot 10^{-3} \mathrm{~h}^{-1}$ ), $\Delta t_{\text {exp }}$ is the respiratory exposure time (usually $0.5 \mathrm{~h}$ ), $T_{\mathrm{w}}$ is the "operating" temperature of the damage medium. With the use of ther- 


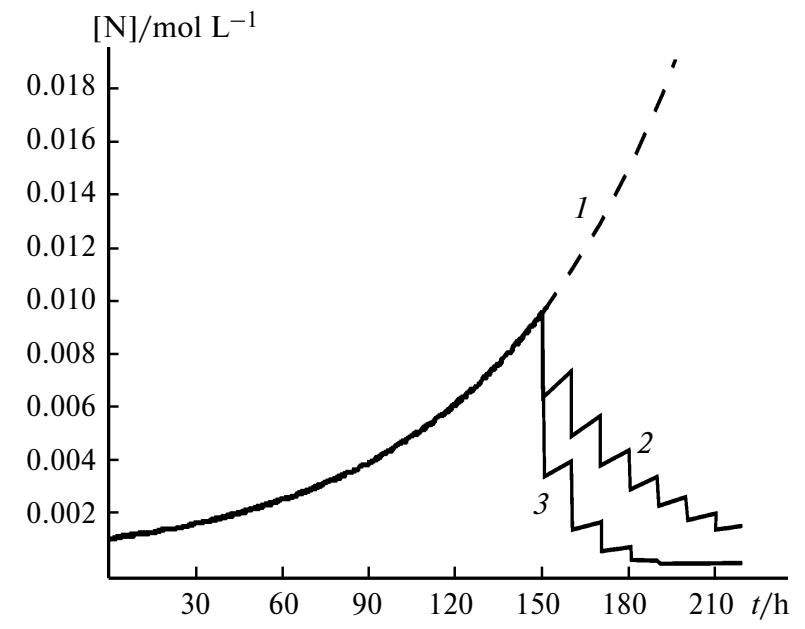

Fig. 6. Variation of the virus concentration $[\mathrm{N}]$ during accumulation without therapeutic procedure (1) and with periodic exposure to thermoheliox at the "operating" temperature $T_{\mathrm{w}}=55(2)$ and $60{ }^{\circ} \mathrm{C}(3)$.

moheliox, the gas mixture enters the respiratory system at the rated temperature $T_{\mathrm{N}}$, while the outlet temperature of the mixture is usually $10-20{ }^{\circ} \mathrm{C}$ lower. It follows from Eq. (7) that at the "operating" temperature of $50{ }^{\circ} \mathrm{C}$, $[\mathrm{N}] /[\mathrm{N}]_{0}=0.91$, while at 60 or $65^{\circ} \mathrm{C}$, this ratio is 0.41 or 0.056 , respectively. In other words, at $50^{\circ} \mathrm{C}$, thermoheliox destroys only approximately $10 \%$ of the viruses, while about half of the viruses are destroyed at $60^{\circ} \mathrm{C}$, and more than $90 \%$ of the viruses are destroyed at $65^{\circ} \mathrm{C}$.

Thus, the kinetic model considered here describes the key features of the development of an acute viral infection in a human body and makes it possible to outline pathways for elaboration of a new method for fighting the viral infection.

\section{References}

1. C. Beauchemin, A. Handel, BMC Public Health, 2011, 11, S7.

2. P. Baccam, C. Beauchemin, C. A. Macken, F. G. Hayden, A. S. Perelson, J. Nirol., 2006, 80, 7590.
3. J. A. Kellum, Crit. Care, 2000, 4, 6.

4. S. D. Varfolomeev, S. V. Kalyuzhnyi, Biotekhnologiya: Kineticheskie osnovy mikrobiologicheskikh protsessov [Biotechnology: Kinetic Grounds of Microbiological Processes], Vysshaya shkola, Moscow, 1990, 296 pp. (in Russian).

5. S. D. Varfolomeev, K. G. Gurevich, Biokinetika. Prakticheskii kurs [Biokinetics. Practical Course], FAIR-PRESS, Moscow, 1999, 720 pp. (in Russian).

6. S. D. Varfolomeev, Khimicheskaya enzimologiya [Chemical Enzymology], Nauchnyi mir, Moscow, 2019, 480 pp. (in Russian).

7. S. D. Varfolomeev, A. T. Mevkh, Prostaglandiny - molekulyarnye bioregulyatory: biokinetika, biokhimiya, meditsina [Prostaglandins as Molecular Bioregulators: Biokinetics, Biochemistry, Medicine], Izd-vo MGU, Moscow, 1985, 307 pp. (in Russian).

8. M. G. Sergeeva, A. T. Varfolomeeva, Kaskad arakhidonovoi kisloty [Arachidonic Acid Cascade], Narodnoe obrazovanie, Moscow, 2006, 256 pp. (in Russian).

9. J. E. Bailey, D. F. Ollis, Biochemical Engineering Fundamentals, McGraw-Hill, New York, 1986, 984 pp.

10. L. V. Shogenova, M. Ya. Godyaev, A. V. Tret 'yakov, S. Yu. Novoselov, M. A. Kutsenko, A. A. Panin, A. G. Chuchalin, Moskovskaya Meditsina [Moscow Medicine], 2019, 2, 96 (in Russian).

11. T. G. Kim, L. V. Shogenova, M. Yu. Martynov, E. M. Gusev, A. A. Panin, XXVIII Natsional'nyi Kongress Organov Dykhaniya [XXVIII National Congress of Respiratory Organs] (Moscow, October 16-19, 2018), Abstrs, DizainPress, Moscow, 2019, p. 71 (in Russian).

12. L. V. Shogenova, M. Y. Godyaev, A. V. Tretyakov, A. A. Charapkin, S. Y. Novoselov, A. A. Panin, A. G. Chuchalin, T. G. Kim, Proc. Int. Conf. of ERS (Madrid, September 28October 2, 2019), Madrid, 2019, p. 110.

13. Registration Certificate for the Medical Device RNZ 2016 $\ 3988$. "Heliox Extreme" Apparatus: No. 10197: publ. 20.04.2016/ Applicant: LLC Medtekhinnovatsii (in Russian). 